\title{
Increasing Learning Motivation Through the Application of Physics Education Technologies Combined with Experiments
}

\author{
Ganti Riang Somasi Manao*, Septina Severina Lumbantobing, Manogari \\ Sianturi, Faradiba
}

Physics Education, Faculty of Teacher Training and Educaion, Christian University of Indonesian, Jakarta, 13630, Indonesia

Corresponding Email: gantiriangm@gmail.com

\begin{abstract}
This study aims to compare the increase in student motivation through the application of PhET with PhET combined experiments. The study was conducted at SMAN 42 Jakarta in odd semester 2019/2020. This type of research is a quasi-experiment with two group pre-test post-test group design research designs. The sample was 64 students. Sampling using cluster random sampling. Class XI IPA 3 as class A is applied to PhET simulation combined experiments and class XI IPA 1 as class B is to be applied to PhET simulation. The instrument used was a questionnaire resulting from learning motivation in the form of 20 statements. The results showed that there was an effect of the application of PhET in combination with experiments on learning motivation with an average initial score of 51.25 for class A and 3.53 for class B, while the final average score of 80.97 for class A and 75.81 for class B. The results of the manova test obtained the statistical value of the multivariate test component which is greater than 0 and close to 1 and the test results of between subjects effects also obtained a significantly smaller value than the significant requirement of $0,000(0,000<0.05)$ for motivation which means the influence an increase in student learning motivation so it is concluded there is an effect of the application of PhET compared to the application of PhET combined experiments on increasing student motivation.
\end{abstract}

Keywords: motivation, PhET, experiments

\section{INTRODUCTION}

Conventional learning conditions that are dominated by lectures will place the teacher as a source of information (teacher centered) so that students as learning objects become very passive because only see and listen, students are not taught at all learning models that can understand how to learn about a variety of material, think and motivate self (Trianto, 2009)

The implementation of conventional learning models emphasizes the learning objectives in the form of additional knowledge and general depiction so that the learning process is seen as a process of memorizing, imitating, and repeating according to what the teacher and student have to say to be able to reveal the knowledge learned through quizzes or tests. In this case students are less motivated to take part in learning because they are accustomed to working on problems without knowing the concept of the material so students will experience difficulties when faced with modified questions.

Motivation is the basic thing in the form of strength that pushes someone to do something to reach the goal. Motivation can also be said to be the overall driving force within students that gives rise to learning activities, which ensures continuity of learning activities and gives direction to learning activities. If someone faces a challenge, and he feels himself capable, then usually that person will try to do the activity (Uno, 2018).

The learning process that takes place without the use of instructional media that can visualize abstract processes that cannot be seen directly by the eyes of students will result in a lack of student motivation in learning. This will cause students to be less challenged 
in participating in learning so that it will cause a lack of student motivation. Learning that takes place with experiments can also support learning activities by applying theory so that students easily understand the material and can construct knowledge with the experimental process itself. The higher the involvement of students in practical activities, the higher the achievement of students' understanding and motivation in learning (Widayanto, 2009). Therefore, researchers are interested in conducting research aimed at comparing the increase in student motivation through PhET with PhET combined experiments.

\section{METHODS}

\section{$2.1 \quad$ Location and time research}

This research was conducted in SMAN 42 Jakarta at Jl. Rajawali Halim Perdana Kusuma, East Jakarta (13650) in the odd semester of Academic Year 2019/2020.

\subsection{Sampling}

The sampling method is cluster random sampling. The sample of this study was class XI IPA 3 as class A and class XI IPA 1 as class B, each class consisted of 32 students.

\subsection{Type and design of research}

This type of research used is quasi experimental research. Class A was given PhET treatment combined with experiments and class $\mathrm{B}$ was given PhET treatment in the learning process with rigid objects equilibrium material. The research design used was two group pretest posttest design, with the following table 1.

Table 1: Desain of Research

\begin{tabular}{|l|l|l|l|}
\hline Class & Pretest & Treatment & Posttest \\
\hline $\mathrm{A}$ & \multirow{2}{*}{$0_{1}$} & $\mathrm{X}_{1}$ & \multirow{2}{*}{$0_{2}$} \\
\cline { 3 - 4 } $\mathrm{B}$ & $\mathrm{X}_{2}$ & \\
\hline
\end{tabular}

(Rusdi, 2018)

Information:

$0_{1}$ : pretest

$\mathrm{X}_{1}$ : treatment of PhET simulation media combined with experiments

$\mathrm{X}_{2}$ : treatment of PhET simulation media

$\mathrm{O}_{2}:$ posttest

\subsection{Data Collection Technique}

Data collection techniques in this study were student questionnaires and worksheets. The questionnaire used aims to determine student learning motivation before and after the application of PhET simulation media combined with experiments in class $\mathrm{A}$ and the use of PhET simulation media in class B.

\subsection{Data Analysis Technique}

In this study, data analysis technique used is the technique of descriptive statistics and quantitative analysis by processing the data after completion of the study using SPSS 24 software application for windows. For each indicator the comparison of student learning outcomes is done by comparing learning motivation before and after being treated in class A and class B.

\subsubsection{Normality Test}

Normality test is a test conducted to see the research data were normally distributed or not. Testing normality of the data using SPSS 24 for windows to see the results of significant value in the Kolmogorov Smirnov. A significance level used in this study was 0.05 . If the value of the significant level of $>0.05$, normally distributed data, and if the value of the significant level obtained $<0.05$ then the data were not normally distributed.

\subsubsection{Homogeneity Test}

Homogeneity test is a test conducted to obtain the data similarity with testing through the application of SPSS 24 for windows through Levene test to see statistically significant value table test of homogenity of Variances. Data is said to be homogeneous when significant numbers obtained $>0.05$ and is said to be homogeneous when significant numbers $<0.05$.

\subsubsection{Hypothesis Test}

Hypothesis test in this research using t-test (ttest) aided software SPSS 24 for windows through independent sample t-test with a significance level of 0.05 or $5 \%$. It can be seen if sig. (2-tailed) $<0,05$, then the hypothesis is proven that means null and alternative hypothesis $\mathrm{H}_{0}$ rejected and $\mathrm{H}_{1}$ accepted. 


\subsubsection{Gain Test}

Gain test is performed to determine the results increased student motivation through learning the average grade of using the following equation :

$$
g=\frac{\text { score posttest }- \text { score pretest }}{\text { scoreideal }- \text { score pretest }}
$$

Through the above equation, it can be obtained the classification of increasing student motivation with the provisions based on the following table :

Table 2: Classification Index Gain.

\begin{tabular}{|l|l|}
\hline Value Gain & Criteria \\
\hline $0,00<\mathrm{g} \leq 0,30$ & Low \\
\hline $0,30<\mathrm{g} \leq 0,70$ & Moderate \\
\hline $0,70<\mathrm{g} \leq 1,00$ & High \\
\hline
\end{tabular}

\section{RESULTS AND DISCUSSION}

\subsection{Description of the results of student learning motivation questionnaire}

The results of the pretest test of student motivation showed that the average value for class $\mathrm{A}$ was 51.25 and the average value for class B was 53.53. This shows that the initial motivation of class $A$ is lower than class B even though both classes are in the category of moderate learning motivation. The following is a bar chart for each indicator of student motivation for class A and class B.

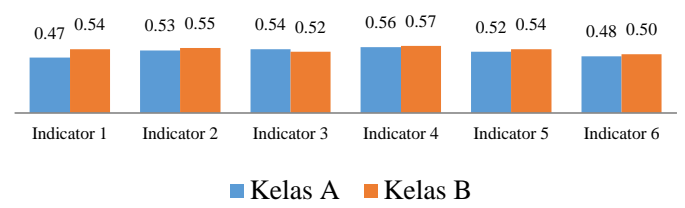

Figure 1: Bar Chart Classification Indicator Early Learning Motivation Class A and Class B

Judging from the classification of learning motivation, it can be seen from Figure 1 that the results of the initial motivation of students in class A and class B show that learning motivation is almost the same as the average of the highest motivation seen in indicator 4 (there is an appreciation in learning) that is 0.56 for class A and 0.57 for class B. While for the lowest average motivation seen in indicator 1 (the existence of desire and desire to succeed) in class $\mathrm{A}$ is 0.047 and in indicator 6 (the existence of a conducive learning environment) in class B is 0.48 . The bar diagram shows that the initial motivations of class $\mathrm{A}$ and class $\mathrm{B}$ are in the medium classification for all the indicators. This is because the treatment has not been given to the two classes.

The results of the post-test of students' motivation showed that the average value for class A was 80.97 and the average value for class B was 75.81. This shows that the final motivation of class $\mathrm{A}$ is higher than class B even though both classes are in the category of high learning motivation. This shows that after being given treatment in the two classes, there is a change in learning motivation between class A using PhET simulation media combined with class B using only PhET simulation media in the learning of rigid objects equilibrium. The following is a bar chart for each indicator of student motivation for class A and class B.

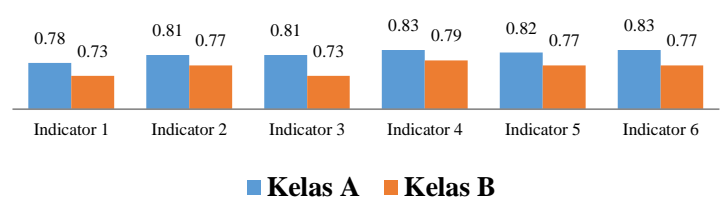

Figure 2: Bar Chart of Classification Indicators of Final Learning Motivation Class A and Class B

Judging from the classification of learning motivation, it can be seen from figure 2 that the final motivation results of students in class A and class B show the highest learning motivation on indicators 4 (the existence of rewards in learning) and 6 (the existence of a conducive learning environment) for class A. Whereas for class B, the highest is in indicator 4 (there is an appreciation in learning). The lowest learning motivation of students in class A can be seen in indicator 1 (the existence of desire and desire in learning), while in class B it is seen in indicator 1 (the desire and desire in learning) and 3 (the existence of hopes and ideals for the future). The difference in increase for each indicator is caused by the treatment given to each class, where for class A which is applied to the PhET simulation media combined with experiments has a much greater increase compared to class B which is applied to the PhET simulation media alone. However, for each indicator of student learning motivation after being given treatment both for class $\mathrm{A}$ and class B are at a high classification for all indicators. This shows that the application of PhET simulation media can increase student motivation especially when combined with experiments will experience an increase in higher learning motivation. This is caused by the experiments conducted that can give effects that make students more interested and challenged to deepen the material learned. 


\subsection{Prerequisite Test Data Analysis}

After obtaining pretest and posttest data, the normality test was conducted using SPSS 24 based on the Kolmogorov Smirnov test with a significant value> 0.05 . The results of the normality test calculation use pretest data for class A and class B.

Table 3: Normality Test Calculation Results

\begin{tabular}{|l|l|l|l|l|}
\hline Tests of Normality \\
\hline & \multicolumn{3}{l|}{ Kolmogorov-Smirnov } & Category \\
\cline { 2 - 5 } & Statistic & df & Sig. & \\
\hline Class A & 0.120 & 32 & 0.200 & Normal \\
\hline Class B & 0.146 & 32 & 0.081 & Normal \\
\hline
\end{tabular}

Based on table 2, data obtained with a class A significant value of 0.200 and significant for a class B of 0.081 . Both classes have significant values $>0.05$, so it can be stated that the data is normally distributed. In other words, the sample from the study is normally distributed.

Homogeneity test in this study used the Levene test on SPSS 24 with the following results:

Table 4: Homogeneity Test Calculation Results

\begin{tabular}{|l|l|l|l|}
\hline \multicolumn{3}{|c|}{ Test of Homogeneity of Variances } \\
\hline Levene Statistic & $\mathrm{df}_{1}$ & $\mathrm{df}_{2}$ & Sig. \\
\hline 0.089 & 1 & 62 & .766 \\
\hline
\end{tabular}

Based on table 4 , it can be seen that the significant value is 0.766 , if the value is compared with the significance level $=0.05$, the significant value obtained is greater than the significance level $(0.766>0.05)$. From the test results, it can be concluded that the sample from the study came from a homogeneous population.

Hypothesis testing uses the independent sample ttest with the following results:

Table 5: Independent Sample t - Test Results Learning Motivation Test

\begin{tabular}{|l|l|l|l|}
\hline \multirow{2}{*}{ Class A Vs B } & $d f$ & Sig. & Information \\
\cline { 2 - 4 } & 62 & 0.000 & $\begin{array}{l}\text { There are significant } \\
\text { difference }\end{array}$ \\
\hline
\end{tabular}

From the data processing results obtained significance of student learning motivation of 0,000 . This value is smaller than the significant level value, so it can be concluded that the $\mathrm{H}_{\mathrm{a}}$ hypothesis is accepted, that is the motivation of student learning which is applied by the PhET simulation media combined with experiments in the learning process is higher than the students who applied the PhET simulation media alone. In other words, there is a significant difference between learning motivation in class A and class B. This is caused by the use of PhET simulation media which is more interesting in terms of appearance and the presence of games that make students more challenged. Student learning motivation is also increasing because the PhET simulation media combined with experiments can make students more desirous and motivated to be more curious and challenged with the learning activities that take place.

Based on the average value of students' learning motivation in class $\mathrm{A}$ and class $\mathrm{B}$, then the average value of normalized gain can be seen in the following table 6.

Table 6: Value and Criteria of Gain

\begin{tabular}{|l|l|l|}
\hline Class & Value & Criteria \\
\hline A & 0,61 & Moderate \\
\hline B & 0,48 & Moderate \\
\hline
\end{tabular}

Based on table 6 shows that the PhET simulation media combined with experiments in class A obtained a value of learning motivation gain of 0.61 in the medium category. While in class B the normalized gain of learning motivation is 0.48 in the medium category. the criteria for the gain values of class A and class B are in the medium category, but seen from the value of the gain class $\mathrm{A}$ has a higher value than class $\mathrm{B}$. Another thing that causes the value of the gain in class A and class B has a value that is not too far away or equal the same as being in the medium category is the first time PhET simulation media was used in physics learning so that it resulted in students needing adjustments to the learning activities that took place.

\section{CONCLUSIONS}

There is an effect of the application of PhET in combination with experiments on increasing student motivation with an initial average score of 51.25 for class $\mathrm{A}$ and 3.53 for class $\mathrm{B}$, while the final average score of 80.97 for class A and 75.81 for class B Based on the results of the independent sample t test, it was found that the significant value was smaller than the significant requirement, which was $0,000 \quad(0,000$ $<0.05$ ), which meant that HA was accepted, that is the result of student motivation applied by the PhET simulation media combined with experiments in the learning process higher than students. which is applied to the PhET simulation media.

\section{SUGGESTIONS}

PhET simulation media combined with experiments should be applied at school more than twice so that 
students are accustomed to adjusting to the learning activities that take place. For further researchers, researchers are expected to endeavor to attract students' attention by creating enjoyable learning situations so that it is more conducive.

\section{REFERENCES}

1. Adams, W. K., Perkins, K. K., Podolesfky, N. S., Dubson, M., Finkelstein, N. D., \& Wieman, C. E., 2006. New Instrument for Measuring Student Beliefs about Physics and Learning Physics: The Colorado Learning Attitudes about Science Survey. Physics Education Research, 1-14.

2. Hamalik, O., 2001. Proses Belajar Mengajar. Jakarta: Bumi Aksara.
3. Trianto., 2009. Model-Model Pembelajaran Inovatif-Progresif. Jakarta: Prestasi Pustaka Publisher.

4. Sadirman, A.M., 2007. Interaksi dan Motivasi Belajar Mengajar. Jakarta: Grafindo.

5. Uno, H. B., 2018. Teori Motivasi dan Pengukurannya. Jakarta: Bumi Aksara.

6. Widayanto., 2009. Pengembangan Keterampilan Proses dan Pemahaman Siswa Kelas X Melalui KIT Optik. Jurnal Pendidikan Fisika Nasional, 5(1), 1-9.

7. Wiemen., 2010. Development and Validation on Instruments to Measure Learning of Expert - Like Thingking. International Journal of Science Education, 1-24 